\title{
Media debate on obesity prevention in the UK and Sweden
}

\section{Gun Roos}

National Institute for Consumer Research, Oslo, Norway

Obesity prevention has recently gained a great deal of attention from researchers, policy makers and the mass media. At the political level international and national policy documents with focus on obesity prevention and health promotion are being developed and implemented $(1,2)$. The World Health Organization (WHO) has raised prevention of overweight and obesity as a serious global public health concern (1). It is widely recognized that a range of information is needed to be able to prevent obesity successfully. To add to the understanding of options for the prevention of obesity, current media debates in the UK and Sweden were analysed. The UK was selected since a dramatic increase in the prevalence of obesity has spurred a lively British media debate. To obtain a Nordic perspective Sweden, where a white paper is currently being developed (2), was included in the analysis. The specific research questions were: Who are the key actors and who is given the responsibility for obesity prevention in the media debates? What obesity prevention measures and strategies are described in the media debates?

The Internet editions of one major national newspaper in each country, The Guardian in the UK and Dagens Nyheter in Sweden, were selected as data sources. The Internet archives of the newspapers over 1 year (September 2003 to August 2004) were searched for newspaper articles using the keyword 'obesity'. All newspaper articles that included information on actors or causes and/or obesity prevention strategies were included in the analysis.

Obesity seems currently to be a bigger media topic in the UK than in Sweden. The preliminary search of The Guardian resulted in 810 news articles, of which 199 fulfilled the selection criteria and were included in the analysis. The Guardian covered research and obesity-related reports published by various authorities, organizations and groups. For example, the activities of the Food Standards Agency, an independent food safety watchdog, made the news frequently. There was also extensive commentary related to government actions, including preparation of a white paper dealing with advertising and food labelling, and a campaign aimed at increasing everyday physical activity. The search of the archives of Dagens Nyheter resulted in 24 news items, of which all fulfilled the criteria and were included in the analysis. The main news item in Sweden was the development of the new national policy and action plan for good food habits and increased physical activity (2). There is a possibility that part of the reason for the great difference in the number of articles between the two newspapers is a result of differences in indexing systems. However, a pronounced need for action in the UK seems to be reflected in the observation that one-fifth of the headlines in The Guardian included war metaphors (e.g. time bomb, war, attack) whereas in Dagens Nyheter only one headline indicated domestic conflict ('Chip-eating dads lose the carrot war').

The media debates on obesity prevention in both the UK and Sweden seem to recognize that obesity is complex and related to both individual behaviour and environmental factors. The main responsible actors were, according to both newspapers, the government and the food industry. Because of the focus on children and obesity, schools and parents were also pointed out as important actors. In addition, in the UK the roles of advertising, individuals' sedentary lifestyles and social inequality were discussed. In the Swedish newspaper there were some references to the responsibility of agricultural policy in the development of obesity.

A wide range of obesity prevention strategies (national policies, information, restrictions on advertising, food labelling, price policies, activities at school, physical activity, etc.) was discussed in 
both newspapers. More strategies were presented in The Guardian than in Dagens Nyheter (this was in part a result of the disparity in the number of articles). Strategies for regulating the marketplace (e.g. restrictions or bans on food advertising, vending machines at school, a 'traffic light' labelling system indicating which foods are good or bad for health) and efforts to reduce inequalities were debated in The Guardian. A tension between government, commercial and consumer responsibilities was clearly present. There was not much recognition in the UK press that there is a shared responsibility across actors. National policies were seen as important, but there seemed to be an ongoing discussion about what the government can and should do. Should the government control or are the authorities only supposed to empower citizens to take control of their own lives? The dilemma with the division of responsibilities in the UK was highlighted in discussions about the 'nanny state' interfering with the rights of individuals to choose their own lifestyles. Because government officials bring legitimacy it was not surprising that there was a lot of emphasis in the media on white papers as prevention strategies. The press in Sweden, representing a Nordic welfare state, reflected more a consensus that the government is responsible for developing a national strategy plan. The responsibilities of the food industry and retailers were especially discussed in the UK press, maybe in part because retailers have so much power in the UK food system. However, the Swedish media also suggest that the food industry should take more responsibility in the types of products that they produce and how they are labelled. Current global and national strategies $(1,2)$ have brought more emphasis on environmental factors.
The results from this analysis indicate that there is some distance to go before the WHO's goal of establishing integrated multisectoral strategies is reached.

This was a limited study, but the analysis showed that obesity has become an increasingly important political and ethical issue, which is debated in the press. There were clear references to the policy options, labelled 'look to corporate action' (e.g. voluntary labelling, new product development) and 'frame market conditions' (e.g. tax, marketing controls, guidelines, training in schools) (3). The two other policy options, to do nothing or to empower civil society to demand and consume differently (e.g. civil action, class actions, skills training, alternative supply chains) were referred to less often. However, focus on civil society may become more important in the future because consumption, food and health issues have become increasingly politicized (4).

\section{References}

1. World Health Organization. Global strategy on diet, physical activity and health. Resolution WHA57.17. Geneva: WHO; 2004.

2. Underlag till handlingsplan för goda matvanor och ökad fysisk aktivitet. www.slv.se

3. Lang T, Heasman M. Food wars: the global battle for mouths, minds and markets. London: Earthscan; 2004.

4. Micheletti M. Political virtue and shopping: individuals, consumerism, and collective action. New York: Palgrave Macmillan; 2003.

\section{Gun Roos}

National Institute for Consumer Research

PO Box 4682

Oslo, Norway

E-mail: gun.roos@sifo.no 